\author{
Micraedes, Coq. \\ Limatus, Theob. \\ Isostomyia, Coq. \\ Simondella, Laveran. \\ Mochlostyrax, D. \& K. \\ Phoniomyia, Theob. \\ Sabethes, R.-D. \\ Lesticocampa, D. \& K. \\ Sabethoides, Theob. \\ Wyeomyia, Theob. \\ Runchomyia, Theob. \\ Dendromyia, Theob. \\ Joblotia, Blanchard. \\ Trichoprosopon, Theob.

\section{A NEW SPECIES OF MEGARHINUS.} \\ BY FREDERICK KNAB, WASHINGTON, D. C.
}

A small lot of mosquitoes which were recently received from Dr. W. F. Thornton, of Bluefieldis, Nicaragua, contains a single specimen of a Megarhinus, which represents a new species. It is related to the forms with white-ringed tarsi, recently dealt with in a paper by Dr. Dyar and myself (Smithonian Miscellanenus Collections, Quarterly Issue, xlviii, $24 \mathrm{I}-258$, I 906 ), but differs from all the known species in that the white on the hind tarsi does not encircle them, but is upon the outer side only.

Microscopic preparations show that the so-called second and third segments of the male palpus are really one, being only apparently divided by a false joint, a slight constriction accentuated by a difference in the coloration of the scales. The male palpus is, therefore, only four-jointed, consisting of a very short basal joint, a very long second joint (apparently homologous with the third joint of the males of the Culicine and Anopheline forms), a third shorter joint, and a fourth long and sabre-like. In the female there is a fifth very minute terminal joint, hidden beneath a dense vestiture of scales. What has been called the first abdominal segment in previous descriptions is in reality the post-scutellum, which overlaps the basal portion of the abdomen. In the following description, for the sake of uniformity, the palpi are treated as in previous descriptions.

Megarhinus hypoptes, new species.=-Male: Head behind the eyes velvety-black, the eyes broadly bordered with light metallic-blue, beneath and at the sides silvery. Antennæ densely plumose ; the toruli with silvery lustre; second segment long and stout, longer than the three succeeding ones, somewhat compressed iaterally, the heavy scaling of the crest condensed to a prominent iridescent blue patch on the anterior portion. Palpi metallic-blue and purple, segments 2 to 4 pale lilac at the tip, second and fourth segments nearly equal, the third longer, fifth twice as long as the fourth. Prothoracic lobes deep metallic-blue. Mesothorax greenishblack on the disk, with a few coppery scales intermixed; the anterior and

February, igo7 
posterior margins, an ill-defined median line and patches at the middle of the sides metallic-blue. Scutellum and post-scutellum bright metallic-blue. Pleura and coxæ silvery. Abdomen above deep blue, passing from greenish to a violaceous-tinge towards the tip, segments 6,7 and 8 marked with gold at the hind angles, the seventh with a fine golden hind margin. Claspers violet-scaled. Sixth and seventh segments laterally expanded, reaching their greatest width at the tip of the seventh. No catudal tufts. Lateral abdominal cilia pale on all the segments but the last, dark on the eighth and the genitalia. Abdomen beneath yellowishsilvery, with a median blue stripe. The stripe is widest on the third and fourth segments, and narrows to a fine line on the sixth and seventh. Eighth segment violaceous beneath, tipped with gold. Legs deep violet and blue, the hind tarsi only white-marked. Under surface of the femora bright brassy. On the hind legs the fourth and fifth tarsal joints are silvery-white on the outer side, black on the inner. Length, $9.5 \mathrm{~mm}$. (exclusive of appendages).

Type.-Cat. No. 1o, 146, U. S. Nat. Mus.

Locality.-Bluefields, Nicaragua. (W. F. Thornton.)

\section{TWO NEW BEES OF THE GENUS TRIEPEOLUS.}

BY T. D. A. COCKERELL, BOULDER, COLO.

Triepeolus grindelice, n. sp.-- 9 . Length ro-I r mm.; black, the legs red, with black spurs; pubescence pale cinereous, with a slight yellow tint. Wings nearly clear; tegulæ orange ferruginous; mesothorax with two short longitudinal bands of pubescence; antennæe black except the third joint and extreme base of fourth, which are dull red; clypeus with very dense minute punctures, and scattered larger ones; labrum black; mandibles largely red; lower part of pleura bare, densely punctured; scutellum rather prominent, bilobed; lateral teeth black, short but rather sharp ; broad apical bands on abdominal segments 1 to 4 entire; transverse black area on first segment as in helianthi, occidentalis, etc; oblique patches at sides of second segment pointed, and making an angle of about $45^{\circ}$ with apical band; apical segment reddened; pygidial area large and circular; last ventral segment curved downwards at apex. By the shape of the last ventral segment, and the comparatively small size, it is allied only to the Californian T. callopus, Ckll., from which it differs by the larger size, grayer pubescence, circular (instead of oval) pygidial area, black labrum, more strongly bilobed scutellum, etc.

February, 1907 